\title{
The Role of Sharia Accountant for Sustainable Development Goals (SDGs)
}

\author{
Nur Ika Mauliyah \\ University of 17 Agustus 1945, Surabaya \\ nurikamauliyah@gmail.com
}

\begin{abstract}
Accountants have various activities that support every financial reporting activity. Developing Islamic accounting is now increasingly diverse activities the existence of Islamic accounting considered. The United Nations initiated sustainable development goals as SDGs. The SDGs are consensus or agreement from 193 member states of the United Nations (UN) and agreed on their achievements. SDGs has 17 goals and 169 achievement targets with a target of 15 years, namely from 2015-2030. SDGs and financial reports needed in carrying out the desired activities to get achieve the target. Islamic accounting is almost SDGs with sharia accounting with the same goal in advancing a better life. Indonesian Institute of Accountants by making provisions for Islamic accounting guidelines.
\end{abstract}

Key Word: Sharia Accountant, Sustainable Development Goal's

\section{INTRODUCTION}

The concept of development which is attended by countries is currently a concern because it does not have references that are by following those questioned. The United Nations as a world organization paid attention to this and after meeting with the United Nations in the world finally agreed on the concept of development known as the Sustainable Development Goals (SDGs). SDG is an agreement that encourages changes in the direction of development that still pay attention to human rights so that every community has equality in terms of development. The SDGs present in 17 goals for used to eradicate poverty, well-being, health, and climate change which is currently a real global threat.

Islamic accounting is present as a form of scientific discipline as well as real work in the transition to what is expected of the SDGs. Sharia accounting not only improves aspects of poverty eradication, but also improves health, the provision of quality education, infrastructure development, economic growth, even anticipation, climate change, and increasing income inequality. Islamic accountants have a greater expectation to play a role in Indonesia in the use of the Islamic capital market and have a significant role in funding infrastructure projects, contributing to retail are getting better each year.

The Indonesian Institute of Accountants (IAI) is a professional organization that houses all Indonesian accountants. IAI is a forum that represents the Indonesian accounting profession as a whole, both those who practice as public sector 
accountants, private sector accountants, educator accountants, public accountants, management accountants, tax accountants, forensic accountants, and others. The IAI Professional Organization has several sections KASy, KASP, KAKJA, KAPi, and KAPd.

The Sharia Accountant Compartment (KASy), an IAI compartment that focuses on discussing the issue of accounting practices in Indonesia experienced by industry practitioners, such as accountants working in the sharia economic industry, auditors, academics, and sharia industry supervisors. The expertise and practical experience possessed by practitioners of sharia finance, provides valuable contributions to Indonesia, especially in increasing transparency of sharia transaction financial reports in Indonesia. ${ }^{1}$

The Public Sector Accountant Compartment (KASP), is a compartment that wants to have a vision to become an independent, quality, and foremost professional organization in the ethical development and accounting practices of the public sector. While the mission of IAI KASP is to become a forum for maintaining the integrity, commitment and competence of members in developing ethically oriented public management, developing government accounting knowledge and practices, and actively participating in realizing good public governance. ${ }^{2}$

Accountant Office Accounting Compartment (KAKJA), is a compartment whose job is to improve the professionalism of the Main Members of IAI who have permission to establish KJA, carry out professional activities, and scientific functions. IAI KAKJA also has the task to compile and implement Compartment work programs that are in line and line with and in line with IAI DPN Work Program. IAI KAKJA has the authority, responsibility and procedures set out in IAI organization regulations. IAI KAKJA is run by the IAI KAKJA Management and the administrative and operational functions of the IAI KAKJA are carried out by the Central IAI Executive Management. ${ }^{3}$

The Indonesian Accountants Association (IAI-KAPJ) Tax Accounting division is expected to be an organization that can develop the ability of the tax accountant profession who has a career and is involved in the Indonesian taxation world. Thus, accountants are expected to be able to contribute more to the nation and state, especially the taxation sector ${ }^{4}$

The Indonesian Institute of Accountants-Educator Accountant Compartment (IAIKAPd), intends to carry out the National Accounting Symposium (SNA). This symposium is a manifestation of the Indonesian Institute of Accountants program, particularly the Educators Accountant Compartment to advance the quality of accounting education in Indonesia. It is expected to produce recommendations for

\footnotetext{
${ }^{1}$ http://iaiglobal.or.id/v03/kompartemen/statis-kasy-

${ }^{2}$ http://iaiglobal.or.id/v03/kompartemen/tentang-kasp

${ }^{3}$ http://iaiglobal.or.id/v03/kompartemen/statis-kakja-7

${ }^{4}$ http://iaiglobal.or.id/v03/kompartemen/statis-kapj-5
} 
business people and the government to improve the quality of accounting practices in Indonesia. ${ }^{5}$

\section{RESEARCH METHOD}

This study uses qualitative research methods, namely According to Bogdan and Taylor (1975) quoted by Moleong (2007: 4) suggests that qualitative agreement as a research procedure that produces descriptive data in the form of written or oral words from qualitative research people a complete view of a place according to the views of humans. Research Qualitative relating to the ideas, perceptions, opinions or beliefs of people who agree and all of which cannot be returned with numbers.

The study conducted in this study is more qualitative research emphasizes the discussion of literature study. Literature review is a study of the decomposition of theory, research, library study materials. In this study using studies library research (literature research) that uses literature which will be discussed in this research and clearly explain the literature used. Literature study on research by studying the Islamic accounting guidelines issued by IAI and related literature books Islamic accounting. And this research describes as well explain the role of sharia accountants in simple language without minimized the contents and guidelines, with the aim that this research is useful users especially in supporting the SDGs program.

\section{DISCUSSION}

\section{A. Development of Islamic accounting}

Conventional accounting accommodation is patterned in accounting policies such as the international Accounting issue and Auditing Standards for Islamic Financial Institutions (AAOIFI) and PSAK No. 59 or the latest PSAK 101-106 in Indonesia. At that time, sharia accounting had not yet received clear recognition in PSAK, only in 2002 with the adoption of PSAK 59 the existence of Sharia Accounting began to be recognized and applied in Islamic financial institutions. The problems faced in the application of Sharia Accounting today clashed with conflicts of interest between companies that want to maximize profits with a commitment to implement Sharia comprehensively. ${ }^{6}$

According to Iwan Triyuwono and Gaffikin, Sharia Accounting is said to be an effort to condition modern accounting in a humanistic and value-filled form. The aim of creating sharia accounting is the creation of a business civilization with humanist, emancipatory, transcendental and theological views. In this way, the alternative reality is expected to be able to raise full self-awareness of one's obedience and submission to God's power. In connection with the problem of changing accounting theory,

\footnotetext{
${ }^{5}$ ACCA, 2017. The Sustainability Development Goals: Redefining context, risk and opportunity. Diakses tanggal 5 Mei 2018. Tersedia di http://www.accaglobal.com/ content/dam/ACCA_Global/professional-insights/Thesustainable-development-goals/pi-sdgs-accountancy-profession

${ }^{6}$ (PSAK No. 59) tentang Akuntansi Perbankan Syariah. Jakarta: Ikatan Akuntan Indonesia dan Bank Indonesia.
} 
accounting will change to a new paradigm not yet clear. In such a context, Takatera in its introduction presents two strategies to study the nature of accounting as follows: ${ }^{7}$

1. If descriptive accounting studies develop in an isolated atmosphere from intellectual strategies to change current accounting, this will justify past and present accounting rather than interpreting it. Conversely, if a normative accounting study is developed in an atmosphere of isolation without regard to public and organizational problems where accounting is practiced, then this will result in trial failure because it will not result in trial failure because it will not be accepted by the public even if it can explain 'accounting for what is not may'. Then it is important to combine descriptive accounting studies with normative accounting studies to provide a new understanding of what accounting was, what is accounting now and what accounting is in the future.

2. If the intended accounting is "what should be" accounting as a continuation of "what it is" accounting, in a way that will never stop, we will not be able to form "what it is" accounting even though we can offer new interpretations of what is accounting "what it was" and what is accounting now (what it is). The strategy for making an issue now clearly has to deal with future accounting stories, namely creating "what should be" accounting. Instead of "what is" in the field we stop existence.

\section{B. Initiation SDGs}

The UN has initiated the Sustainable Development Goals or objectives called Sustainability Development Goals (SDGs). The Sustainable Development Goals known as SDGsini are 17 goals with 169 achievements. the measurable and the deadline that has been determined by the UN as the world development agenda for the benefit of humans and planet Earth. ${ }^{8}$ This goal was declared jointly by intergovernmental countries in the UN resolution issued on 21 October 2015 as a joint development ambition until 2030. This goal is a continuation or successor to the Millennium Development Goals signed by the leaders of the Consensus or agreements of 193 countries a member of the United Nations (UN) and committed to its achievement. SDGs as a continuation of the previous platform, the Millennium Development Goals (MDGs). The SDGs have 17 goals and169 achievement targets with a target of 15 years $(2015-2030)$.

There are 17 Sustainable Development Goals (SDGs)

1. Without Poverty. in developing countries, including by ensuring conducive policy conditions for, among others, industrial diversification and the There is no poverty in any form in all corners of the world. Ensuring the mobilization of significant resources from various sources, including through expanded

\footnotetext{
${ }^{7}$ Triyuwono, Iwan. dan M. As'udi. 2001. Akuntansi Syariah: Memformulasikan Konsep Laba Dalam Konteks Metafora Zakat. Jakarta: Salemba Empat

${ }^{8}$ Resolusi PBB 21 Oktober 2015
} 
development cooperation, provide adequate and predictable tools for developing countries, especially less developed countries, to implement programs and policies that can end poverty in all its dimensions. Create a policy framework at the national, regional and international levels, based on development strategies that favor the poor and sensitive gender, to accelerate investment in poverty alleviation actions.

2. Without Hunger. No more hunger, achieving food security, improving nutrition, and encouraging sustainable agricultural cultivation. Increasing investment, including through expanded international cooperation, in terms of rural infrastructure, agricultural research and service expansion, technology and plant development and animal genetic banks in the effort to increase agricultural production capacity in developing countries, especially in less developed countries. Improve and prevent trade restrictions and distortions in the world agricultural market, including through the simultaneous removal of all forms of agricultural export subsidies and all other export sizes that have the same effect, according to the mandate of the Doha Development Round. Adopt measures that can ensure the proper functioning of the food commodity market and its derivatives and facilitate access to market information, including food supplies, to limit extreme food price upheaval.

3. Good health and well-being. Ensure healthy living and encourage the wellbeing of all people of all ages. Strengthen the implementation of the WHO Convention Framework on Control of Tobacco in all countries, as appropriate. Support research and development of vaccines and medicines for infectious and non-communicable diseases, which specifically affect developing countries, provide access to affordable basic medicines and vaccines, in accordance with the Doha Declaration on the TRIPS Agreement and Public Health, which assert the right of developing countries to make full use of the provisions in the Aspect Agreement Related to the Trade in Intellectual Property Rights regarding flexibility to protect public health, and especially access to medicines for all. Substantially increase funding and for the recruitment, development, training, and absorption of health workers in developing countries, especially in less developed countries and small island developing countries. Strengthening capacity in each country, especially in developing countries for early warning, risk reduction, and national and global health risk management.

4. Quality Education. Ensuring equal distribution of quality education and increasing learning opportunities for everyone. Building and improving the quality of education facilities that are sensitive to gender, children, disabilities and provide a safe, non-violent, inclusive and effective learning environment for all. By 2020, substantially increasing the number of scholarships available to developing countries, especially less developed countries, small island developing countries and African countries, to enter higher education, including vocational training and information and communication technology, 
engineering, technical programs and science, in developed and other developing countries. By 2030, substantially increase the supply of quality teachers, including through international cooperation for teacher training in developing countries, especially less developed countries and small island developing countries.

5. Gender Equality. Achieve gender equality and empower women and women. Conduct reforms to provide equal rights for women to economic resources as well as access to ownership and control of land and other forms of property financial services, inheritance and natural resources, in accordance by following with national law. Increasing the use of applied technology, especially information and communication technology, to support women's empowerment. Adopt and strengthen clear policies and enforce legislation to encourage gender equality and empower all women and girls at all levels.

6. Clean Water and Sanitation. Ensuring the availability of clean water and sustainable sanitation for everyone. Ensuring the availability and management of sustainable clean water and sanitation for all. By 2030, increasing international cooperation and capacity-building support to developing countries in activities and programs related to water and sanitation, including water harvesting, desalination, water efficiency, wastewater treatment, recycling technology, and reuse. Support and strengthen the participation of local communities in improving water management and sanitation.

7. Clean and Affordable Energy. Ensuring access to affordable, reliable, sustainable and modern energy sources for everyone. By 2030, increasing international cooperation will facilitate access to clean energy research and technology, including renewable energy, energy efficiency, and more advanced and clean fossil fuel technologies, and encourage investment in energy infrastructure and clean energy technologies. In 2030, adding infrastructure and improving the quality of technology to supply modern and sustainable energy services to all developing countries, especially in less developed countries, small island developing countries, and landlocked developing countries, by following their respective program assistance.

8. Economic Growth and Decent Work. Supports sustainable economic development, productive employment and decent work for everyone. Increases Aid for Trade for developing countries, especially less developed countries, including through the Framework Expanded Integrated Work for Technical Assistance Related to Trade for Less Developed Countries. In 2020, developing and operating a global strategy for the young workforce and implementing the Global Labor Pact of the International Labor Organization (ILO).

9. Industry, Innovation, and Infrastructure. Build quality infrastructure, encourage sustainable industrial improvement and encourage innovation. Build durable infrastructure, support inclusive and sustainable industrialization and foster innovation. Facilitating the development of long-lasting and sustainable 
infrastructure in developing countries through increased financial, technological and technical support for African countries, less developed countries, landlocked developing countries, and small island developing countries. Supporting the development of domestic technology, research addition of commodity values. Significantly increase access to information and communication technology and strive to provide universal and affordable access to the internet in less developed countries by 2020.

10. Reducing Gaps. Reducing inequality both within a country and among countries in the world. Implementing the principle of special and differential treatment for developing countries, especially less developed countries, in aby following the WTO agreement. Encourage official development (ODA) requirements and financial flows, including foreign direct investment (FDI), for the countries most in need, especially the least developed countries, African countries, small island developing countries and landlocked developing countries, according to plan and their respective national programs. By 2030, reducing to less than 3 percent of the transaction costs of sending migrants and eliminating shipping corridors that will cost more than 5 percent.

11. Urban and Community Sustainability. Build quality, safe and sustainable cities, and settlements. Build cities and settlements that are inclusive, safe, durable and sustainable. Supporting positive economic, social and environmental relations between urban, peri-urban and rural areas by strengthening national and regional development planning. In 2020, it will substantially increase the number of cities and settlements that adopt and implement integrated policies and plans towards inclusive, resource efficiency, mitigation and adaptation to climate change, disaster resistance, and developing and implementing, in line with the Sendai Framework for Disaster Risk Reduction 2015-2030, and holistic disaster risk management at all levels. Supporting less developed countries, including through financial and technical assistance, in building buildings that are sustainable and durable by utilizing local materials.

12. Responsible Consumption and Production. Guarantees the continuity of consumption and production patterns. Supports developing countries to strengthen scientific and technological capacity to move towards sustainable consumption and production patterns. Develop and implement tools to monitor the impact of sustainable development for sustainable tourism that can create jobs and support local culture and products. Rationalize inefficient fossil fuel subsidies that actually encourage overconsumption by eliminating market irregularities, according to the national situation, including by restructuring taxes and gradually reducing harmful subsidies, where they are, to reflect on their impact on the environment, by looking at specific needs and the conditions of developing countries and minimize the adverse effects on the 
development of these countries in a way that protects the poor and affected communities.

13. Action Against Climate. Act quickly to combat climate change and its effects. Take immediate action to combat climate change and its effects. Implement commitments made by developed countries to the United Nations Framework Convention on Climate Change with the aim of mobilizing together $\$ 100$ billion annually by 2020 from all sources to meet the needs of developing countries in the context of mitigation actions and transparency in their implementation and fully operate the Green Climate Fund (GCF) through its capitalization as soon as possible. Support mechanisms for capacity building for effective climate change planning and management in less developed and small island developing countries, focusing on women, youth and local and marginal communities.

14. Underwater Life. Conserve and maintain the sustainability of the sea and the life of marine resources for sustainable development. Conserve and sustainably utilize marine, oceanic and maritime resources for sustainable development. Increasing scientific knowledge, developing research capacity and transfer of marine technology, by looking at the Criteria and Guidelines of the Oceanographic Intergovernmental Commission on the Transfer of Marine Technology, in order to improve marine health and increase the contribution of marine biodiversity to the development of developing countries, especially developing island nations small and less developed countries. Providing access to marine resources and markets for small fishermen. Increase conservation and sustainable use of the sea and its resources, as stated in paragraph 158 of "The Future We Want".

15. Life on the land. Protect, restore, and improve the sustainable use of terrestrial ecosystems, sustainably manage forests, reduce barren land and land swaps. Protect, restore and support sustainable use of terrestrial ecosystems, manage forests sustainably, combat desertification (desertification), and inhibits and reverses land degradation and inhibits loss of biodiversity. Mobilize and significantly increase financial resources from all kinds of sources to carry out conservation and sustainable use of biodiversity and ecosystems. Mobilize significant resources from all sources and all levels to fund sustainable forest management and provide appropriate incentives for developing countries to implement such management models, including for conservation and reforestation. Increase global support for efforts to combat hunting and selling protected species, including increasing the capacity of local communities to obtain sustainable welfare opportunities.

16. A Strong Justice and Peace Institution. Improving peace including the community for sustainable development, providing access to justice for all people including institutions and being responsible for all groups. Supporting a peaceful and inclusive society for sustainable development, providing access to justice for all and building effective, accountable and inclusive institutions at all 
levels. Strengthening relevant national institutions, including through international cooperation, for capacity building at all levels, especially in developing countries, to prevent violence and fight terrorism and crime. Support and encourage non-discriminatory laws and policies for sustainable development.

17. Partnerships to Achieve Goals. Strengthen implementation and revive global partnerships for sustainable development.

\section{SDGs and Accounting.}

Sustainable Development Goals or objectives are called Sustainable Development Goals (SDGs). The inclusive role of accountants towards SDGs 2030 is quality education, sustainable Indonesian economic development, poverty alleviation, institutional strengthening and innovation ${ }^{9}$

SDGs and Implications of L / K according to Ersa Tri Wahyni 2018:

1. PSAK 60 (2014) - Financial Instruments; Disclosure The purpose of this PSAK is to require entities to provide disclosures in financial statements that enable users to evaluate:

2. PSAK 57 (2014 Adjustments): Provisions, Contingent Liabilities, and Contingent Assets.

3. PSAK 48: Impairment of Asset Value and Positive Fiscal Correction

4. PSAK 24 is a set of accounting statements about employee benefits in the company.

5. PSAK 19: Intangible Assets.

6. PSAK 55/71: Calculation of Allowance for Impairment Losses (CKPN).

\section{SDGs Financial Report}

Intangible assets are non monetary assets that are identified without physical form. Some PSAKs that can be used by companies that include SDGs in the financial statements include:

1. Rapid Technology Change and SFAS 48 Impairment of Asset Value

2. Provision for Environmental Costs and SFAS 57 Provisions, Contingent Liabilities and Contingent Assets

3. Risk Management and disclosures in PSAK 60 Financial Instruments: Disclosures

4. Calculating Environmental Risk in the SFAS 71 Financial Instrument Impairment Model

5. Gender Equality and PSAK 24 Employee Benefits

6. Research and Development Burden and SFAS 19 Intangible Assets

\footnotetext{
${ }^{9}$ http://iaiglobal.or.id/v03/kongresxiii/seminar.html
} 


\section{E. SDGs Islamic Accounting}

Islamic accounting is influenced by three factors namely human, world, and profit. Which of these three things are mutually sustainable to build sustainable development. SDGs themselves in the Islamic realm include Sharia CSR, Zyariah Philanthropy (Ziswaf), (Green) Industry and Halal (Real Sector), and Islamic Finance Industry (Tabarru ').

Islam has five sharia mashed or sharia objectives, namely hifdz ad-din (preserving religion), hifdz an-nafs (preserving lust), hifdz al 'aql (preserving reason), hifdz an-nasb (preserving offspring), and hifdz al-maal (maintaining wealth). The interesting thing is that most of the concepts presented by WCED and the target of sustainable development set by the UN are by following the shariah mashed.

Islamic economics or Islamic economics that has these goals should be able to implement sustainable development programs better. Conventional economics views human needs as unlimited and resources are limited. In contrast to conventional economics, Islamic economics can prevent humans from losses due to overexploitation. In Islam, there are certain limits and this can be a control of human activities so that they can utilize and preserve the environment properly.

In addition to environmental preservation, economic growth is also included in the UN's sustainable development agenda. Islamic finance is very relevant to the achievement of Sustainable Development Goals (SDGs) because its principles emphasize equitable distribution of income and have an orientation to environmental social activities.

Two intrinsic features that underlie Islamic finance, namely risk-sharing and the relationship between financial transactions and the real economy. All financial contracts supported by real sector assets and risk-sharing between partners cause sharia financial instruments to be relatively more stable compared to conventional instruments and tend to be more flexible to unexpected shocks (Alawode, 2013). ${ }^{10}$

Chairman of the OJK Board of Commissioners Muliaman D Hadad said that Islamic finance could be one of the world's solutions in achieving the Sustainable Development Goals (SDGs) targets set by the United Nations (UN). Muliaman expressed his views when he was a speaker at the Sharia Finance Seminar in Washington DC, The United States organized by the World Bank and Islamic Financial Services Board.

Sharia finance is also not only able to reach poverty eradication aspects but also includes improving health, providing quality education, gender equality, infrastructure development, economic growth, anticipating climate change and also reducing the level of income inequality.

OJK as the authority of the financial services sector in Indonesia continues to drive the development of the sharia financial sector starting from the sharia banking sector, sharia IKNB, and sharia capital markets. 2015 to $4.81 \%$ in July 2016. The said

\footnotetext{
${ }^{10}$ https://pesceria.wordpress.com/2016/10/28/pembangunan-berkelanjutan-dan-peran-keuangan-syariah/
} 
share is expected to reach around $5.13 \%$ if it takes into account the results of the conversion of the Aceh BPD into a Sharia Commercial Bank. ${ }^{11}$

1. SDGs and Maqashid Sharia based on the Baznas PUSKAS, a zakat study on SDGs confirms that:

a) Without Poverty, Maqashid Sharia is a treasure, a level of need for daruriyah.

b) Without starvation, Maqashid Sharia is the soul and treasure, the level of necessity daruriyah.

c) Healthy and prosperous life, Maqashid Sharia is soul and wealth, daruriyah health level.

d) Quality education, intellectual Maqashid Sharia, levels of daruriyah needs.

e) Gender equality, Maqashid Sharia is wealth, intellectual, life, education, level of needs of daruriyah.

f) Clean water and proper sanitation, Maqashid Sharia is soul and offspring, the level of daruriyah needs

g) Clean and affordable energy, Maqashid Sharia is descendant, the level of Hajj needs.

h) Decent work and economic growth, Maqashid Sharia is a treasure, the level of daruriyah needs.

i) The innovation and infrastructure industry, Maqashid Shariah is a treasure, the level of hajiyah needs.

j) Reducing inequality, Maqashid Sharia is a treasure, the level of demand for daruriyah.

k) Sustainable cities and settlements, Maqashid Sharia are descendants, lives and possessions, the level of Hajj needs.

1) Responsible consumption and production, Maqashid Sharia is a descendant and soul, the level of Hajj's needs.

m) Handling climate change, Maqashid Sharia is hereditary and intellectual, the level of Hajj needs.

n) Oceanic ecosystems, Maqashid Sharia are descendants, wealth, and intellectuals, the level of Hajj needs.

o) Terrestrial ecosystems, Maqashid Sharia are descendants, the level of Hajj needs.

p) Peace of justice and a resilient institution, Maqashid Sharia is soul, property, and offspring, the level of daruriyah needs.

q) Partnership to achieve the goal, Maqashid Shariah property, and intellectual property, the level of Hajj needs.

2. ZIS and SDGs cover five things including:

a) conomy (Wealth)

b) Social and humanity (Lineage)

c) Health (Life)

\footnotetext{
${ }^{11} \mathrm{https}: / /$ swa.co.id/swa/trends/ojk-keuangan-syariah-solusi-tujuan-pembangunan-berkelanjutan
} 
d) Education (Intellectual / Intellectual)

e) Da'wah (faith / Religion)

3. The Role of Zis and SDGs (Puskas Baznas)

a) Objective l: eradicate poverty

b) Objective 2: end hunger

c) Objective 3: good health and well-being

d) Objective 4: quality education

e) Goal 5: clean water and sanitation

\section{F. Sharia Accountant and SDGs}

The purpose of SDGs is overseen by three determination, namely IAI KASy (sharia accountant), IAI DSAS, and IAI KAPd (Sharia Accounting Lecturer Forum). So that SDGs are implemented according to religion. DSAS and SDGs are by following the objectives of the SDGs, then derivatives in the form of fatwas that require compliance (Maqashid Sharia), and finally the implementation is by following the standards set by following Sharia PSAK.

The accounting standard itself is in the form of recognition (records and journals), measurement (price and value), presentation (assets, liabilities, equity, income, expenses / expenses. Zakat, and al-qardh), then disclosure (financial / accounting and non-financial / accounting).

IAI KAPd (Sharia Accounting Lecturer and SDGs) is an accelerated islamic accounting curriculum in which there are four aspects involved in it namely fintech or financial technology, SDGs, Revin 4.0, and Regulation.

\section{CONCLUSION}

Sustainable development goal's as SDGs have an important role in changing the lives of the world community. In carrying out its role, Islamic accounting has the same vision as SDGs. The 17 objectives of SDGs are interrelated with the role and contribution of accounting. The role of accounting will make the achieve of SDGs faster because accounting has advantages such as being able to narrow the gender gap, to be able to maintain and advocate for women in the partnership profession. Accounting is also able to improve the quality of education, support economic growth, promote responsible consumption and production, advance climate action and safeguard peace and justice. That is because accounting can provide transparency and uphold justice so that every activity, especially related to finance, is reported in real terms. 


\section{REFERENCES}

ACCA, 2017. The Sustainability Development Goals: Redefining context, risk and opportunity. Diakses tanggal 5 Mei 2018. Tersedia di http://www.accaglobal.com/ content/dam/ACCA_Global/professional-insights/The-sustainabledevelopment-goals/pi-sdgs-accountancy-profession.pdf

Elizabeth, Santiya. 2018. Supporting Sustainable Development Goals 2030 in Indonesia: Is CONNECT the Answer?. Fakultas Ekonomi. Universitas Katolik Widya Mandala. Surabaya

Fitiyah, Hadiah. 2018 Journal Of Accounting Science Vol. 2 No. 1 EISSN 2548-3501 Journal Homepage: http://ojs.umsida.ac.id/index.php/jas

IFAC, 2016. The 2030 Agenda for Sustainable Development. Diakses tanggal 5 Mei 20tainable-development

Makarenko,I and Plastun,A, 2017. The role of accounting in sustainable development. Accounting and Financial Control (openaccess) , 1, 4-12

Mukhlisin, Murniati. 2016. Etika Menjadi Keprihatinan AkuntanSyariah. Lampung: Simposium Nasional Akuntansi XIX

PWC, 2017.SDGs Reporting Challenge 2017. Diakses tanggal 27 Maret 2018. Tersedia di https://www.pwc.com/gx/en/sustainability/SDG/pwc-sdg-reporting-challenge2017-final.pdf

(PSAK No. 59) tentang Akuntansi Perbankan Syariah. Jakarta: Ikatan Akuntan Indonesia dan Bank Indonesia.

SDG Compass (n.d.), SDG Compass: The Guide for Business Action on the SDGs. Diakses darihttps://sdgcompass.org/wpcontent/uploads/2016/05/019104 SDG Compass Guide2015v29.pdfpada tanggal 19 Juni 2018

Triyuwono, Iwan. dan M. As'udi. 2001. Akuntansi Syariah: Memformulasikan Konsep Laba Dalam Konteks Metafora Zakat. Jakarta: Salemba Empat.

United Nations. (2016). UN Global Compact and Accenture Strategy 2016 CEO Study. Diakses tanggal 27 Maret 2018. Tersedia di https://www. accenture.com/usen/insight-unglobal-compact-ceo-study. 
The Role of Sharia Accountant for Sustainable Development Goals (SDGs)

Wahyuni, Ersa Tri. Dampak SDGs dalam Laporan Keuangan dan Peran Penting Akuntan. Majalah Akuntan Indonesia edisi Juni 2018 halaman 24-26.

http://iaiglobal.or.id 